\title{
Glucosinolates in Brassica: occurrence and significance as cancer-modulating agents
}

\author{
B Y WIM M. F. JONGEN \\ Department of Food Science, Wageningen Agricultural University, PO Box 8129, 6700EV \\ Wageningen, The Netherlands
}

\section{Les glycosinolates}

\begin{abstract}
RÉSUMÉ
Les légumes brassicas comprennent toutes sortes de choux, choux de Bruxelles, broccolis, choux-fleurs, choux-raves, navets et rutabagas. Ils appartiennent à famille des crucifères et sont connus en botannique sous le nom de Brassica. Les brassicas sont fréquemment consommés par les hommes des cultures occidentales et orientales aussi bien que par les animaux. Aux Pays-Bas, on ne connaît pas précisément les quantités consummées par les hommes, mais plus de $36 \mathrm{~g}$ brassicas y sont disponibles par personne et par jour. La saveur typique des brassicas est en grande partie due à des molécules volatiles dérivées du glycosinolate. Il semble que la présence de glycosinolates dans les plantes pour la consommation humaine est limitée aux crucifères. La composition chimique et la présence de glycosinolates et de leurs produits de dégradation ont été étudiées. Il est possible que les niveaux de glycosinolates totaux dans les plantes dépendent de la variété, des conditions de culture, du climat et des pratiques agronomiques, alors que les niveaux dans une plante particulière varient selon les parties de la plante. Dans les plantes, les glycosinolates et leurs produits d'hydrolyse agissent comme des allélochimiques, qui sont des composés qui affectent les comportement, la santé et la croissance d'autres espèces.

Du point de vue de la toxicologie, tous les produits volatiles d'hydrolyse des glucosinolates sont intéressants. Parmi les problèmes liés à la consommation de ces composés, ceux affectant la thyroïde ont été étudiés de façon plus approfondie. Dans la plupart des études sur les animaux réalisées dans le passé, la goitrogénicité induite par les produits dérivés des glycosinolates s'est révélée être limitée à des situations de déficience en iode. Dans une étude sur la fonction thyroïdienne aucun effet des glycosinolates n'a pu être retrouvé (McMillan et al. 1986).

On a suggéré que les produits dérivés des glycosinolates deviennent mutagènes et cancérigènes après nitrosation. Dans une étude approfondie, on a recherché dans plusieurs brassicas hollandais leur potentiel à former directement des composés mutagènes de nitrosyl en réponse à un traitement de nitrite. Ce potentiel a été comparé avec les niveaux des glycosinolates. On a étudié la formation de produits nitrosés d'indole-3-acétonitrile, indole-3-carbinol et indole, en portant une attention particulière à la stabilité de ces produits. Ces études ont révélé que les composés indoliques présents dans les brassicas peuvent être nitrosés et devenir mutagènes à la nitrosation. Cependant les produits nitrosés ne sont stables qu'en présence de grandes quantités de nitrite libre. La nitrosation des glucosinolates et de leurs produits dérivés ne constitue pas un danger significatif pour la santé.
\end{abstract}


En revanche, le données épidémiologiques indiquent qu'une consommation de crucifères est associée à une réduction de l'incidence du cancer dans les populations humaines (Graham et al. 1978; Graham \& Mettlin, 1979; Graham, 1983; Hirayama, 1986). Plusieurs principes actifs ont été identifiés comme produits dérivés de glycosinolates, et il a été montré que l'explication probable des effets protecteurs observés est l'induction d'enzymes du système de biotransformation. L'effet protecteur semble être dû à une modification dans l'équilibre entre les systèmes enzymatiques activants (associés aux cytochromes P450) et les systèmes enzymatiques désactivants (conjugants) favorisant la désactivation de mutagènes et de cancérigènes connus.

\section{OCCURRENCE}

Brassica vegetables comprise all kinds of cabbages, Brussels sprouts, broccoli, cauliflower, kohlrabi, turnip and swede. They belong to the family of Cruciferae, and are botanically known as Brassica species. Brassicas are frequently consumed by humans from both Western and Eastern cultures (Fenwick \& Heaney, 1983; Hill et al. 1987), as well as by animals. In the Netherlands, the amounts consumed by humans are not known exactly, but more than $36 \mathrm{~g}$ brassica per person per $\mathrm{d}$ are available (Godeschalk, 1987).

The typical flavour of brassicas is largely due to glucosinolate-derived volatiles. The occurrence of glucosinolates in plants for human consumption appears to be limited to cruciferous plants. The chemistry and occurrence of glucosinolates and their breakdown products has been reviewed extensively by van Etten \& Wolff (1973) and by Fenwick et al. (1983). Glucosinolates contain a common structure (Fig. 1), with different substituents (alkyl, alkenyl, alkylthioalkyl, aryl, $\beta$-hydroxyalkyl or indolylmethyl groups) at the side chain. Currently more than 100 different glucosinolates have been characterized. The levels of total glucosinolates in plants may depend on variety, cultivation conditions, climate and agronomic practice, while the levels in a particular plant vary between the parts of the plant. Table 1 gives data for the types and levels of glucosinolates occurring in Dutch vegetables (Tiedink et al. 1988).

In plants glucosinolates and their hydrolysis products act as allelochemicals, which are compounds affecting behaviour, health and growth of other species. For instance, the white butterfly, Pieris rapae, is attracted to brassicas, and probably needs glucosinolates for essential functions, while in general, glucosinolates and their hydrolysis products also have insecticidal and fungicidal properties. In higher plants the hydrolysis product of indolylglucosinolates, indole-3-acetonitrile (I3A) and indole-3-acetic acid formed from I3A (Gmelin \& Virtanen, 1961), also act as hormones (auxins).

Glucosinolates can be hydrolysed by myrosinase (thioglucoside glucohydrolase; $E C$ 3.2.3.1), an enzyme also present in Cruciferae, which becomes active when cells are damaged, e.g. by cutting or chewing. Myrosinase hydrolyses glucosinolates by splitting off the glucose, the unstable aglucone then eliminates sulphate by a Lossen rearrangement (Fig. 2). The structure of the resulting products depends on a variety of factors, but in general isothiocyanates, nitriles and thiocyanates are formed. Lessvolatile compounds such as epithionitriles and oxazoldine-2-thiones are formed from glucosinolates with an hydroxyl group at the 2-position of the side chain. Myrosinase can be inactivated by heating, although equivocal data exist about the levels of inactivation. Bradfield \& Bjeldanes (1987) only found a $20 \%$ reduction in myrosinase activity after 


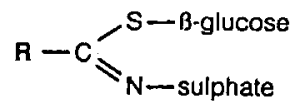

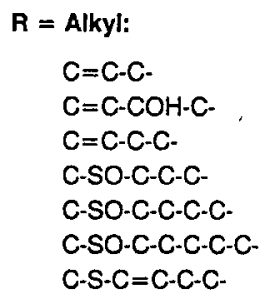<smiles>[R4]c1cccc2c1c(C[14CH3])cn2-c1ccccc1</smiles>

\author{
Sinigrin \\ Progoitrin \\ Gluconapin \\ Glucoiberin \\ Glucoraphanin \\ Glucoalyssin \\ 4-Methylthiobutenyl- \\ glucosinolate
}

Glucosturtiin

Glucobrassicin

4-Hydroxy-glucobrassicin

4-Methoxy-glucobrassicin

Neoglucobrassicin

Fig. 1. Chemical structure of the most commonly occurring glucosinolates in cruciferous vegetables.

Table 1. Types and levels of glucosinolates occurring in Dutch vegetables (From Tiedink et al. 1988)

\begin{tabular}{|c|c|c|c|c|c|c|c|c|c|c|c|c|c|c|c|c|}
\hline \multirow[b]{3}{*}{ Vegetables } & \multicolumn{16}{|c|}{ Glucosinolates ( $\mu \mathrm{mol} / \mathrm{g}$ dry wt vegetable) } \\
\hline & \multicolumn{10}{|c|}{ Aryl- and alkyl-glucosinolates } & \multicolumn{5}{|c|}{ Indolyl-glucosinolates } & \multirow{2}{*}{$\begin{array}{r}\text { Total } \\
(1-13)\end{array}$} \\
\hline & 1 & 2 & 3 & 4 & 5 & 6 & 7 & 8 & 9 & Total & 10 & 11 & 12 & 13 & Total & \\
\hline Cauliflower & 0.2 & - & 0.2 & - & $0 \cdot 3$ & - & - & - & - & 0.7 & $0 \cdot 1$ & 0.7 & 0.2 & $0 \cdot 1$ & $1 \cdot 1$ & $1 \cdot 8$ \\
\hline Brussels sprouts & $3 \cdot 1$ & $7 \cdot 6$ & $8 \cdot 2$ & $2 \cdot 1$ & $0 \cdot 3$ & 7.0 & $0 \cdot 3$ & - & - & $28 \cdot 3$ & $1 \cdot 2$ & $4 \cdot 5$ & 0.9 & - & $6 \cdot 6$ & $34 \cdot 9$ \\
\hline Savoy cabbage & $4 \cdot 3$ & $0 \cdot 3$ & $4 \cdot 3$ & 0.4 & $0 \cdot 3$ & 0.4 & - & - & - & $10 \cdot 0$ & 0.4 & $2 \cdot 4$ & $1 \cdot 8$ & $0 \cdot 1$ & $4 \cdot 7$ & $14 \cdot 7$ \\
\hline Broccoli & 0.5 & $6 \cdot 2$ & - & $5 \cdot 9$ & $0 \cdot 3$ & $0 \cdot 6$ & - & - & - & $13 \cdot 5$ & - & $2 \cdot 1$ & $0 \cdot 2$ & 0.9 & $3 \cdot 2$ & $16 \cdot 7$ \\
\hline Red cabbage & $1 \cdot 6$ & $1 \cdot 2$ & $2 \cdot 7$ & $0 \cdot 3$ & $0 \cdot 1$ & 0.4 & - & - & - & $6 \cdot 2$ & $0 \cdot 1$ & $3 \cdot 8$ & $0 \cdot 3$ & - & $4 \cdot 2$ & $10 \cdot 4$ \\
\hline Green cabbage & $7 \cdot 3$ & 0.2 & $10 \cdot 2$ & - & $0 \cdot 2$ & - & - & - & - & 17.9 & - & $6 \cdot 8$ & $1 \cdot 3$ & - & $8 \cdot 1$ & $26 \cdot 0$ \\
\hline Oxheart cabbage & 0.7 & $0 \cdot 3$ & $0 \cdot 1$ & 0.9 & $0 \cdot 3$ & - & - & - & - & $2 \cdot 3$ & $0 \cdot 1$ & $1 \cdot 1$ & $0 \cdot 1$ & - & $1 \cdot 3$ & $3 \cdot 6$ \\
\hline White cabbage & $6 \cdot 8$ & $0 \cdot 2$ & $4 \cdot 2$ & $0 \cdot 1$ & 0.2 & - & - & - & - & $11 \cdot 5$ & - & $3 \cdot 4$ & 0.4 & $0-1$ & $3 \cdot 9$ & $15 \cdot 4$ \\
\hline Kohlrabi & $0 \cdot 2$ & - & - & $0 \cdot 2$ & $0 \cdot 1$ & - & - & - & - & $0 \cdot 5$ & $0 \cdot 1$ & $1 \cdot 3$ & $0 \cdot 1$ & 0.5 & $2 \cdot 0$ & $2 \cdot 5$ \\
\hline Chinese cabbage & - & - & - & - & - & - & 0.5 & - & - & 0.5 & - & $1 \cdot 3$ & 1.5 & $0 \cdot 1$ & 2.9 & $3 \cdot 4$ \\
\hline Swede & - & $2 \cdot 3$ & - & - & 0.7 & - & $2 \cdot 9$ & - & 0.5 & $6 \cdot 4$ & $0 \cdot 2$ & 0.9 & 0.3 & 0.9 & $2 \cdot 3$ & $8 \cdot 7$ \\
\hline Radish & - & $0 \cdot 2$ & - & - & $0 \cdot 2$ & - & - & 4.9 & 0.7 & $6 \cdot 0$ & $0 \cdot 2$ & $0 \cdot 3$ & 0.5 & - & 1.0 & $7 \cdot 0$ \\
\hline Horseradish & - & - & - & - & $0 \cdot 2$ & - & - & $9 \cdot 6$ & $0 \cdot 4$ & $10 \cdot 2$ & $0 \cdot 3$ & 0.3 & $0 \cdot 1$ & - & 0.7 & $10 \cdot 9$ \\
\hline
\end{tabular}

1, Glucoiberin; 2, progoitrin; 3, sinigrin; 4, glucoalyssin; 5, glucoraphanin; 6, gluconapin; 7, glucosturtiin; 8 , 4-methylthiobutenylglucosinolate; 9 , the rest of the aryl- and alkyl-glucosinolates; 10, 4-hydroxyglucobrassicin; 11, glucobrassicin; 12, 4-methoxyglucobrassicin; 13, neoglucobrassicin. 
cooking cauliflower (Brassica oleracea) for $10 \mathrm{~min}$, while McMillan et al. (1986) detected only about $0-2 \cdot 5 \%$ of its original activity in Brussels sprouts after cooking for $9 \mathrm{~min}$. Slominsky \& Campbell (1987) found complete inactivation of myrosinase when rapeseed (Brassica napus) meal was heated to $95^{\circ}$ for $10 \mathrm{~min}$, although substantial decomposition of glucosinolates was observed during heating. Glucosinolates are lost during cooking of cruciferous vegetables due to leaching into the cooking liquor (Srisangham et al. 1980; Fenwick et al. 1983). The effects of processing on glucosinolate levels in vegetables have been reviewed by de Vos \& Blijleven (1988). On hydrolysis of indolylglucosinolates (Fig. 3) unstable isothiocyanates are formed which degrade to indole-3-carbinol (I3C), while under more acidic conditions I3A and elemental S are formed. I3C may condense to diindolylmethane (DIM) or react with ascorbic acid to form ascorbigen (ASC).

\section{GLUCOSINOLATE-MEDIATED TOXIC EFFECTS}

\section{Goitrogenic effects}

From a toxicological point of view all the volatile hydrolysis products of glucosinolates are of interest. Among the problems associated with the consumption of these compounds, those affecting the thyroid have been studied most extensively (van Etten, 1969). Thiocyanate ions and oxazolidine-2-thiones are goitrogenic in animals, although the mechanisms involved seemed to be different. Thiocyanate ions are considered to behave as iodine competitors and, therefore, will cause goitrogenicity only in cases of iodine deficiency, while oxazolidine-2-thiones interfere with thyroxine synthesis and, therefore, will be goitrogenic irrespective of the iodine status. Additionally, some isothiocyanates and nitriles may also lead to goitrogenic symptoms resulting from the thiocyanate-mediated detoxification process. In most animal studies performed in the

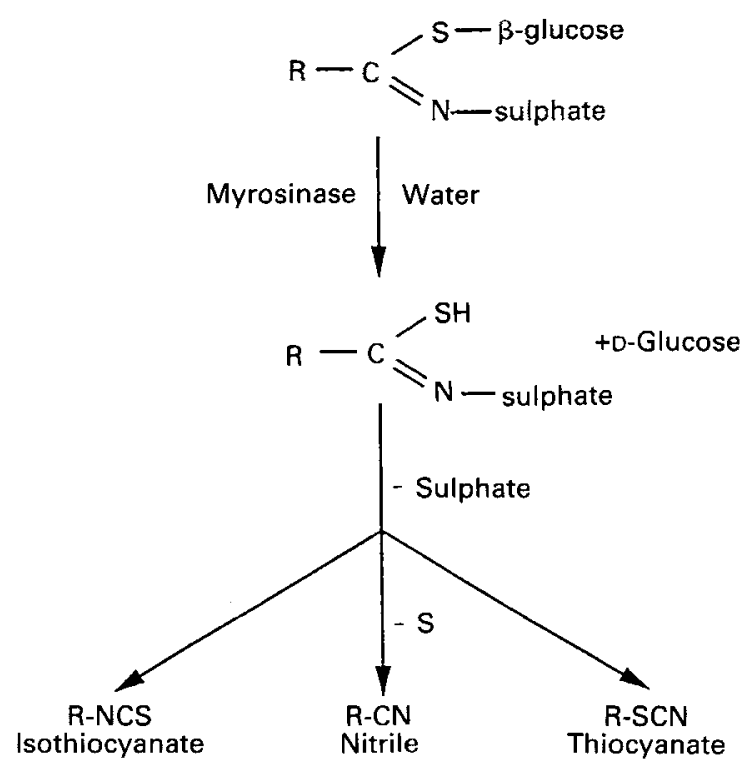

Fig. 2. Common structure of glucosinolates and their breakdown products formed on myrosinase $(E C$ 3.2.3.1) hydrolysis. 


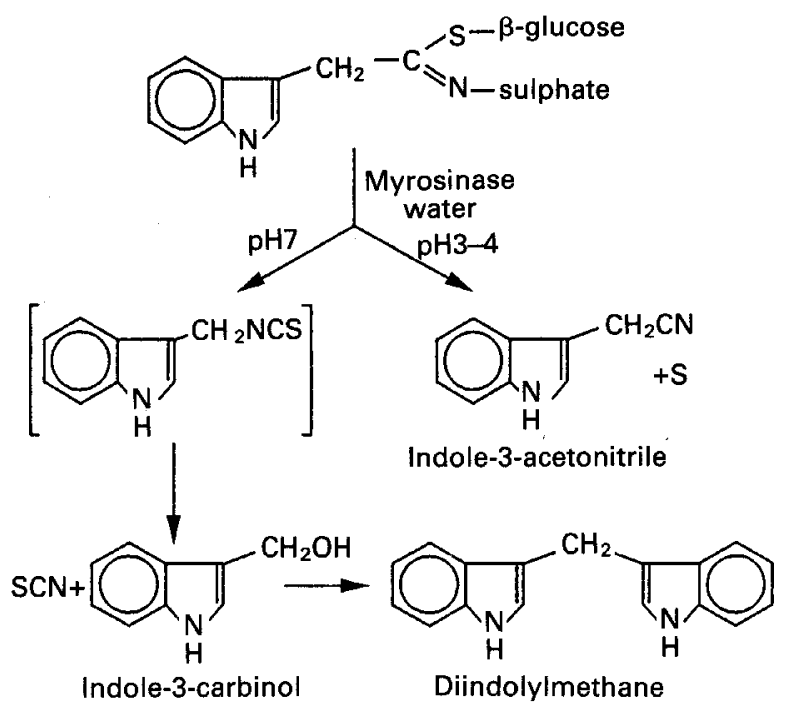

Fig. 3. The breakdown products of indolylglucosinolates on myrosinase ( $E C$ 3.2.3.1) hydrolysis.

past, goitrogenicity induced by glucosinolate breakdown products appeared to be limited to situations of iodine deficiency. In a study of McMillan et al. (1986), no effects on human thyroid function could be found, as measured by the levels of thyroid-stimulating hormone, triiodothyronine and thyroxine after a daily consumption of $150 \mathrm{~g}$ Brussels sprouts over a period of 9 weeks.

In addition to the effects of glucosinolate breakdown products on the thyroid other effects have been observed. Hydroxynitriles and glucosinolates themselves were suggested to be responsible for enlargement of adrenal glands, kidneys and liver in rats after long-term feeding of rapeseed and for liver haemorrhage observed in poultry. Several isothiocyanates have been shown to be embryotoxic in rat, while in in vitro studies a number of them appeared to be cytotoxic and mutagenic. Moreover, allylisothiocyanate is able to induce tumours in rats (National Toxicological Programme, 1981).

\section{Nitrosation of glucosinolates}

In many studies the presence of large amounts of compounds susceptible to nitrosation in food products was investigated by nitrosation of extracts of these food products followed by total $\mathrm{N}$-nitroso compound (NOC) determination or by measurement of alkylating and/or mutagenic activity. In most of these studies the experimental conditions during nitrosation were modifications of the so-called nitrosation assay procedure which is the test protocol adopted by the World Health Organization to investigate the occurrence of compounds susceptible to nitrosation in drugs. After nitrite treatment sauerkraut, pickled vegetables, Chinese cabbage (Brassica pekinensis) and fava beans (Vicia faba) contained direct mutagenic activity (Piacek-Llanes \& Tannenbaum, 1982; Wakabayashi et al. 1983, 1984, 1985; van der Hoeven et al. 1984; Jongen et al. 1987; Groenen \& Bussink, 1988). Further work showed that I3A, 4-methoxyindole-3-acetonitrile and 4-methoxyindole-3-aldehyde could act as precursors of NOC in Chinese cabbage (Wakabayashi et al. 1985, 1986). 
Since these indole compounds are hydrolysis products of glucosinolates Tiedink et al. $(1988,1989,1990,1991)$ paid special attention to the human relevance of the role of indole compounds and glucosinolates in the formation of NOC in vegetables. Vegetables commonly consumed in the Netherlands were screened for their potential to form directly mutagenic NOC on nitrite treatment. For brassicas this potential was compared with their glucosinolate levels. The formation of nitrosated products of $\mathrm{I} 3 \mathrm{~A}, \mathrm{I} 3 \mathrm{C}$ and indole were studied and special attention was paid to the stability of these products. After investigation of the hydrolysis of purified glucosinolates by myrosinase and acid, the contribution of intact and hydrolysed glucosinolates, as well as several known indole compounds, to the total mutagenicity of nitrite-treated brassica extracts was studied. These studies revealed that the indole compounds present in Brassica vegetables can be nitrosated and thereby become mutagenic. However, the nitrosated products are stable only in the presence of large amounts of free nitrite. If the food matrix is present during the nitrosation procedure glucosinolates and their breakdown products contribute only marginally to the presence of NOC in these vegetables. Consequently nitrosation of glucosinolates and their breakdown products does not constitute a significant health risk.

\section{GLUCOSINOLATES AS CANCER-MODULATING AGENTS}

\section{The process of tumour formation}

There is abundant epidemiological and experimental evidence that the process of carcinogenesis is a multi-stage process in which at least three distinct phases can be recognized: the initiation phase, the promotion phase and the progression phase (Ponten, 1987). Initiation is the genetic event which is considered to be the first step in the onset of carcinogenesis. Although a chemical that can bind covalently with DNA will do so largely at random, only specific lesions will result in genetic alterations that are relevant for the cancer process, such as activation of oncogenes. The initiation phase comprises two distinct steps: the induction of the molecular lesions and the fixation of these lesions by DNA replication. Promotion is the process whereby an initiated tissue or organ develops focal proliferations of phenotypically altered cells. In its first phase promotion is reversible and promoters appear to act only above a certain threshold level. Promotion can be brought about by aspecific stimuli such as wounding, bacterial infection, cell killing, partial hepatectomy etc. In addition to this aspecific type of effect, promotion can be brought about by specific mitogenic stimuli. For example, growth factors and hormones can act as promoters and other types of promoters can interfere with growth factor pathways, for example, by influencing receptor affinity and binding sites. In vitro studies have shown that many of these proliferative stimuli are triggered by promoter-membrane interactions. Structural and functional changes in cellular membranes have been reported, such as activation or inhibition of plasma-membrane-bound enzymes, modulation of ion transport and transport of small molecules through plasma membranes (Slaga, 1984; Yamasaki, 1984). One major aim of studies on tumour promotion is to determine which components of a cell society are responsible for maintaining dormancy of initiated cells and, as a corollary, how tumour promoters interfere with such societal influence to permit clonal expansion. In the progression phase, one or more of the focal proliferations undergo a cellular evolution to malignant neoplasm. During this evolution these cells acquire several characteristics which can be divided into the following categories: 
infinite growth: there is an indefinite expansion of the net cell number in a tumour, resulting in a progressive increase in tumour burden;

genetic instability: within a tumour new abnormal genotypes are created and fixed, implying a considerable risk of losing important proliferation and differentiation controls;

irregular migration: cells acquire invasive properties, which means that they have the potential to migrate, settle and grow at abnormal locations in the organism.

In experimental animal studies progression is accomplished by addition of initiating agents which induce additional genetic changes.

\section{Role of biotransformation}

Living organisms are continually exposed to a variety of naturally-occurring chemicals. If these compounds are lipophilic they are generally made more hydrophilic by metabolic transformations, mainly oxidations or hydroxylations, and subsequent conjugations to facilitate excretion. This process of metabolic transformation can be divided into two phases. Phase 1 reactions introduce new functional groups into the lipophilic compounds, converting them into highly reactive products which can bind covalently to nucleophilic molecules. Phase 2 metabolism comprises synthetic reactions with small endogenous molecules that are coupled to functional groups originally present or introduced by phase I metabolism. The ability of carcinogens to exert their effects depends largely on the balance between activating and de-activating enzymes. Any change in this balance will result in a change in the biological effect. Many compounds occurring naturally in the human diet modulate the biotransformation of several carcinogens, resulting in reduced tumour incidence (Wright, 1980). This implies compounds which inhibit the formation of electrophilic intermediates by acting as inducers of alternative pathways, as well as compounds which change the balance between activating and de-activating enzyme systems (van Bladeren, 1993). The liver is the organ predominantly involved in the biotransformation of many xenobiotics. For practical purposes, in the majority of in vitro studies, liver homogenates or subcellular fractions have been used to mimic in vivo metabolism. The use of this kind of preparation has several disadvantages. Due to homogenization and fractionation of cells the balance between activating and de-activating enzyme systems is disturbed. In particular, conjugation reactions, which are located in different cellular compartments, are much less operative (Moldeus, 1981). This kind of disadvantage may be overcome by the use of intact cells as a metabolizing system. Isolated hepatocytes resemble the in vivo situation in their structural and biochemical properties much more closely than subcellular fractions (Wortelboer et al. 1990). When freshly-isolated hepatocytes are cultured they show a rapid decline in their capacity for biotransformation. The various isozymes of the cytochrome $\mathrm{P} 450$ family, especially, show a rapid loss of activity. To overcome this problem several methods have been applied, such as addition of hormones, addition of enzyme inducers and co-culture with epithelial cells or on extracellular membranes. Although some of these methods were partially successful in retaining the total cytochrome $\mathbf{P} 450$ activity, selective changes were observed in the pattern of different cytochrome $\mathrm{P} 450$ isozymes (Althaus et al. 1979). In contrast to parenchymal cells isolated from mammalian liver, chick-embryo hepatocytes maintain their initial levels of cytochrome P450 enzyme activities in vitro for at least $3 \mathrm{~d}$ (Topp \& 
van Bladeren, 1986). Moreover, induction with known enzyme inducers such as phenobarbital, 3-methylcholanthrene or Aroclor 1254 resulted in more than a two-fold increase in cytochrome P450 content (Jongen et al. 1987). Also when this system was used to study modulating effects of dietary components such as several indole compounds and the synthetic flavonol $\beta$-naphthoflavone, treatment of cultured chick-embryo hepatocytes with these compounds resulted in increases in activities of both phase I and phase II enzyme systems.

\section{Glucosinolates and cancer prevention}

Epidemiological data indicate that consumption of cruciferous vegetables is associated with a decreased incidence of cancer in human populations (Graham et al. 1978; Graham \& Mettlin, 1979; Graham, 1983; Hirayama, 1986). The anti-carcinogenic properties of cruciferous vegetables and isolated compounds have been studied in several investigations. When animals were first fed on diets high in cruciferous vegetables and then exposed to various indirect-acting carcinogens, tumour yields were lower and survival rates were higher than similarly-treated animals on semi-purified diets (Stoewsand et al. 1978; Boyd et al. 1982; Wattenberg, 1983). A number of these cruciferous plants, including Brussels sprouts, cabbage, cauliflower and broccoli have been found to induce aryl hydrocarbon hydroxylase (EC 1.14.14.1) activity (Wattenberg et al. 1976) and/or the activity of cytosolic glutathioneS-transferase (EC 2.5.1.18) (Sparnins et al. 1982). Subsequently, isolation and identification of the principal compounds involved showed that they were indoles (Loub et al. 1975). When the identified compounds were tested, I3C, I3A, DIM and ASC were shown to inhibit neoplastic effects of carcinogens (for review, see McDanell et al. 1988). However, some specific differences were observed; I3C, DIM and I3A all appeared to inhibit the induction of forestomach neoplasia by benzo(a)pyrene (B(a)P). I3C and DIM also inhibited 7,12-dimethylbenzanthracene-induced mammary tumours, although $\mathrm{I} 3 \mathrm{~A}$ did not (Wattenberg \& Loub, 1978). Initially these effects were thought to be the result of induction of enzymes of the mixed function oxidase (MFO) system (Loub et al. 1975), which can be induced by intact glucobrassicin as well (McDanell et al. 1989). Later, I3C was also found to be an inducer of glutathione-S-transferase, glucuronyl transferase and epoxide hydroxylase (EC 3.3.2.3), enzymes involved in the detoxification of xenobiotics (Sparnins et al. 1982; Cha et al. 1985). The mode of action of this type of anti-carcinogenic compound thus seems to involve a qualitative and quantitative change in the metabolism of the carcinogens (Wattenberg, 1993). In contrast to all these findings, Pence et al. (1986) reported that I3C enhanced dimethylhydrazine-induced tumour formation. Also, indole compounds can enhance the formation of tumours in trout (Salmo fario) when administered after a carcinogen (Bailey et al. 1987). Apparently the type of modulation is largely dependent on the choice of the model carcinogen.

So far in vitro data on the protective effects of pretreatment with indoles against the DNA-damaging capacity of carcinogens are scarce. Probably this is due mainly to the fact that in most in vitro systems it is not possible to induce biotransformation enzymes. The use of in vitro cultures of primary chick-embryo hepatocytes may offer a useful model to study modulating effects of indoles. These hepatocytes maintain their biotransformation capacity in vitro for up to $72 \mathrm{~h}$ without loss of activity. Moreover, induction with known enzyme inducers leads to enzyme induction comparable with that occurring in in vivo situations (Althaus et al. 1979; Giger \& Meyer, 1981; Topp \& van Bladeren, 1986). 


\section{A co-culture system to study mechanisms of glucosinolate-mediated modulation of biotransformation systems}

The system consists of two cell types, primary chick-embryo hepatocytes and V79 Chinese hamster cells. Primary chick-embryo hepatocytes are isolated from 15-d-old chick embryos and cultured for $24 \mathrm{~h}$. After treatment for a specific time with the modulating compound, the compound is removed and V79 cells are added. After $2 \mathrm{~h}$ the mutagen is added and the cells are exposed. If simultaneous treatment is wanted the modulating compound is added together with the mutagen. After exposure the cells are dissociated and the V79 cells are used for determination of changes in the genetic end-points, for example, by plating on microscopic slides for sister chromatid exchange determination or in Petri dishes for measurement of hypoxanthine-guanine phosphoribosyltransferase (EC 2.4.2.8) mutants (Jongen et al. 1989; Jongen, 1993). Using this approach, detailed studies were carried out to investigate the mechanisms underlying observed protective effects of various modulating compounds on B(a)P-mediated mutagenicity (Jongen, 1988). Treatment with I3C, I3A and $\beta$-naphthoflavone resulted in increases in cytochrome $\mathbf{P 4 5 0}$-associated enzyme activities. When metabolite formation of $\mathrm{B}(\mathrm{a}) \mathrm{P}$ was studied, large increases were observed in the amounts of specific metabolites. However, no shift was found in the ratios between the various metabolites when compared with metabolite formation following treatment with the carcinogen 3-methylcholanthrene. Formation of the mutagenic and carcinogenic metabolite, B(a)P-7, 8-dihydrodiol, did not differ between the three compounds. This indicates that induction of cytochrome $\mathrm{P} 450$-associated enzyme activity as such is not an appropriate indicator for modulating capacity. However, pretreatment with $\mathrm{I} 3 \mathrm{C}$ and $\beta$-naphthoflavone followed by exposure to $\mathrm{B}(\mathrm{a}) \mathrm{P}$ resulted in decreased mutagenic effects (Table 2). Experiments with subcellular fractions showed that the mechanisms underlying these protective effects were different for the respective compounds. In the case of $13 \mathrm{C}$ the protective effects result from a changed balance of the enzyme systems involved in the I3C biotransformation process. There is an overall increase in the rate of metabolism, but the increases in conjugating enzyme activity compensate for the increases in cytochrome $\mathrm{P} 450$-associated enzyme activities. In the case of $\beta$-naphthoflavone the available data strongly suggest that the inhibitory effects cannot be ascribed to the inducing capabilities of the compound, but instead seem to be due to the formation of an

Table 2. Inhibitory effect of pretreatment with various enzyme-inducing agents on genotoxicity of some carcinogens (Data from Jongen, 1988)

(Experiments performed using co-culture system)

\begin{tabular}{|c|c|c|c|c|c|}
\hline \multirow[b]{3}{*}{ Compound } & \multirow{2}{*}{\multicolumn{2}{|c|}{ Exposure }} & \multicolumn{3}{|c|}{$\begin{array}{c}\text { Reduction (\%) in } \\
\text { SCE per chromosome }\end{array}$} \\
\hline & & & \multicolumn{3}{|c|}{ Pretreatment with: } \\
\hline & Dose $(\mu \mathrm{g} / \mathrm{ml})$ & Time (h) & $\mathrm{I} 3 \mathrm{C}$ & I3A & $\beta-N F$ \\
\hline $\mathrm{B}(\mathrm{a}) \mathrm{P}$ & $5 \cdot 0$ & 20 & 33 & 30 & 44 \\
\hline DMNA & 1500 & 4 & 46 & - & - \\
\hline 2-AA & $10 \cdot 0$ & 20 & - & - & - \\
\hline
\end{tabular}

I3C, indole-3-carbinol; I3A, indole-3-acetonitrile; $\beta$-NF, $\beta$-naphthoflavone; $\mathbf{B}(\mathrm{a}) \mathbf{P}$, benzo(a)pyrene; DMNA, dimethylnitrosamine; 2-AA, 2-aminoanthracene; SCE, sister chromatid exchange. 
intracellular pool of $\beta$-naphthoflavone which acts as a competitive inhibitor for $\mathrm{B}(\mathrm{a}) \mathrm{P}$ metabolism.

Using enzyme preparations from rat liver and from chick-embryo liver the metabolic fates of the indole compounds I3C and I3A were also studied. The metabolites formed were isolated and identified by GC-MS and NMR studies. It appeared that from both compounds the same metabolites were formed. A first step in this metabolism was the formation of indole-3-carboxaldehyde. The metabolic route resulting in the formation of this intermediate metabolite was different for both compounds. In the case of I3C the microsomal cytochrome P450 system (MFO in Fig. 4) and the cytosolic alcohol dehydrogenase system (ADH) were involved, whereas in the case of $13 \mathrm{~A}$ only the cytochrome $\mathrm{P} 450$ enzyme system appeared to be operative. This difference explains why I3C is metabolized much faster than I3A. The subsequent step was identical for both compounds. Metabolism by the cytochrome P450 system resulted in the formation of the 5-hydroxy-indole-carboxaldehyde metabolite as well as in the formation of the carboxylic acid. The latter metabolite was also formed by the ADH system (Fig. 4). A comparative study between the two types of microsomal preparations showed that there were no differences in metabolic routing. If the same system is operative in the human situation these metabolites could possibly be used as biomarkers.

\section{Problems associated with the study of cancer-modulating compounds}

Selection of mutagen or carcinogen. In 1982 the National Research Council in the USA recommended increased consumption of cruciferous vegetables (National Toxicological
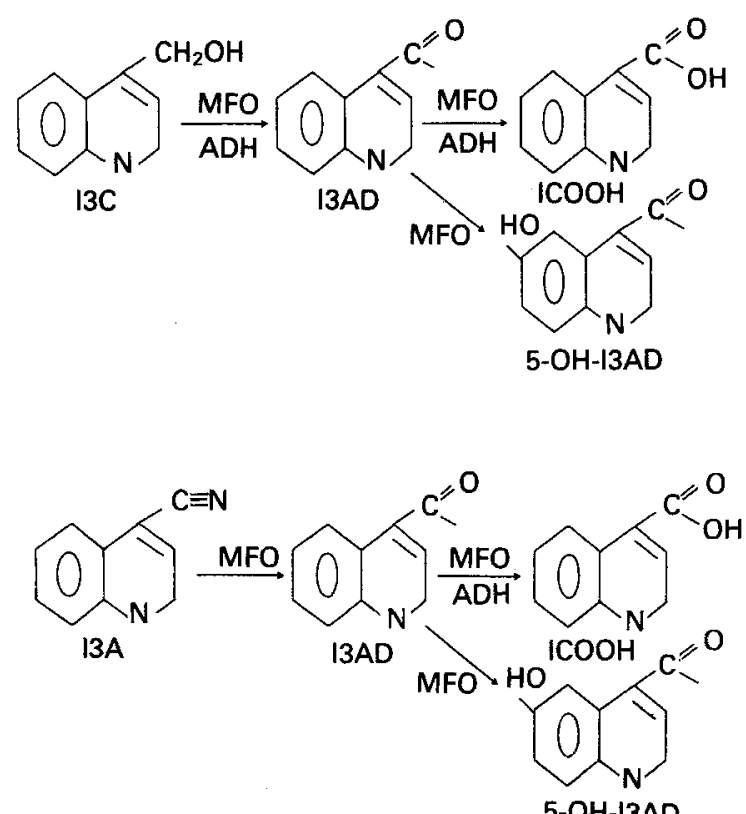

Fig. 4. Metabolites formed from indole-3-carbinol (I3C) and indole-3-acetonitrile (I3A) by microsomal preparations from rat. I3AD, Indole-3-carboxyaldehyde; $\mathrm{ICOOH}$, indole-3-carboxylic acid; 5-OH-13AD, 5-hydroxyindole-carboxaldehyde; MFO, mixed function oxidase system; $\mathrm{ADH}$, alcohol dehydrogenase system. 
Table 3. Modulating effects of indole-3-carbinol pretreatment on sister chromatid exchange (SCE) induction by mutagens from different chemical classes (Data from Jongen et al. 1989)

(Experiments were performed using a co-culture system of primary chick-embryo hepatocytes and V79 Chinese hamster cells)

\begin{tabular}{|c|c|c|c|c|c|}
\hline \multirow[b]{3}{*}{ Compound } & & & \multicolumn{3}{|c|}{ SCE per chromosome } \\
\hline & \multicolumn{2}{|c|}{ Exposure } & \multirow{2}{*}{$\begin{array}{l}\text { Without } \\
\text { pretreatment }\end{array}$} & \multirow{2}{*}{$\begin{array}{c}\text { With } \\
\text { pretreatment }\end{array}$} & \multirow[b]{2}{*}{ Change (\%) } \\
\hline & Time (h) & Dose $(\mu \mathrm{g} / \mathrm{ml})$ & & & \\
\hline $\mathrm{B}(\mathrm{a}) \mathrm{P}$ & 24 & $7 \cdot 5$ & 1.46 & 1.07 & -33 \\
\hline DMNA & 4 & 1500 & 0.91 & $0 \cdot 48$ & -46 \\
\hline 2-AA & 4 & $25 \cdot 0$ & $0 \cdot 81$ & 0.87 & \\
\hline DBE & 4 & $5 \cdot 3$ & $1 \cdot 11$ & 1.45 & +40 \\
\hline EMS & 24 & 100 & 1.04 & 1.02 & \\
\hline Control & 24 & 0 & $0 \cdot 27$ & $0 \cdot 28$ & \\
\hline
\end{tabular}

$\mathrm{B}(\mathrm{a}) \mathrm{P}$, benzo(a)pyrene; DMNA, dimethylnitrosamine; 2-AA, 2-aminoanthracene; DBE, dibromoethane; EMS, ethylmethanesulphonate.

Programme, 1982). At that stage the exact mechanism of the protective effect was not known. Later, several active principles were identified as breakdown products of glucosinolates and it was shown that the probable explanation for the observed protective effects is the induction of enzymes of the biotransformation system. Treatment with the isolated compounds or the vegetables followed by exposure to known carcinogens caused a shift in the balance between activating and conjugating enzyme systems favouring conjugation and resulting in a decrease of the biological activity of the carcinogen. This is an important observation since the majority of known carcinogens are not carcinogenic per se but have to be activated by enzymes of the biotransformation system to become biologically active. This also has important consequences for the conclusions which can be drawn from this type of experiment. Bioactivation of carcinogens from different chemical classes occurs through different biochemical pathways and in the case of halogenated compounds can be brought about also by conjugating enzymes (Jongen et al. 1982; van Bladeren et al. 1993). In the case of the brassica compounds exposure to carcinogens which are activated by conjugating systems will lead to increased effects instead of reduced effects. Apparently the outcome of this type of study depends largely on the choice of the carcinogen to which the animals are exposed. In Table 3 an example is given of the effects of pretreatment with I3C, one of the breakdown products of glucobrassicin, on the mutagenic effects of compounds from different chemical classes. Mutagenicity was determined by measurement of the number of sister chromatid exchanges. Using the co-culture system consisting of primary chick-embryo hepatocytes and V79 Chinese hamster cells it was shown that in the case of $\mathrm{B}(\mathrm{a}) \mathrm{P}$ and dimethylnitrosamine pretreatment with $\mathrm{I} 3 \mathrm{C}$ resulted in decreased biological activity, whereas in the case of dibromoethane pretreatment resulted in enhanced mutagenic effects. From these observations it is clear that the choice (of combinations) of the appropriate model carcinogen(s) is a crucial step in the setup of experimental research. 


\section{REFERENCES}

Althaus, F. R., Sinclair, J. F. \& Meyer, U. A. (1979). Drug-mediated induction of cytochrome(s) P450 and drug metabolism in cultured hepatocytes maintained in chemically defined medium. Journal of Biological Chemistry 25, 2148-2152.

Bailey, G. S., Hendricks, J. D., Shelton, D. W., Nixon, J. E. \& Pawlowski, N. E. (1987). Enhancement of carcinogenesis by the natural anticarcinogen indole-3-carbinol. Journal of the National Cancer Institute 78, 931-934.

Boyd, J. N., Babish, J. G. \& Stoewsand, G. S. (1982). Modification by beet and cabbage diets of aflatoxin B1-induced rat plasma $\alpha$-fetoprotein elevation, hepatic tumorigenesis and mutagenicity of urine. Food and Chemical Toxicology 20, 47-54.

Bradfield, C. A. \& Bjeldanes, L. F. (1987). High performance liquid chromatographic analysis of anticarcinogenic indoles in Brassica oleracea. Journal of Agricultural and Food Chemistry 35, 46-49.

Cha, Y. N., Thompson, D. C., Heine, H. S. \& Chung, J. H. (1985). Differential effects of indole, indole-3-carbinol and benzofuran on several microsomal and cytosolic enzyme activities in mouse liver. Korean Journal of Pharmacology 21, 1-11.

de Vos, R. H. \& Blijleven, W. G. H. (1988). The effects of processing on glucosinolate in cruciferous vegetables. Zeitschrift für Lebensmittel-Untersuchung und -Forschung 187, 525-529.

Fenwick, G. R. \& Heaney, R. K. (1983). Glucosinolates and their breakdown products in cruciferous crops, foods and feedingstuffs. Food Chemistry 11, 249-271.

Fenwick, G. R., Heaney, R. K. \& Mullin, W. J. (1983). Glucosinolates and their breakdown products in food and food plants. CRC Critical Reviews in Food Science and Nutrition 18, 123-201.

Giger, U. \& Meyer, U. A. (1981). Role of haem in the induction of cytochrome P450 by phenobarbitone. Biochemical Journal 198, 131-135.

Gmelin, R. \& Virtanen, A. I. (1961). Glucobrassicin, the precursor of $\mathrm{SCN}^{\sim}$, 3-indolylacetonitrile and ascorbigen in Brassica oleracea species. Annales Academiae Scientiarum Fennicae 107, 3-23.

Godeschalk, F. E. (1987). Consumptie van voedingsmiddelen in Nederland in 1984 en 1985 (Consumption of Vegetable Products in the Netherlands in 1984 and 1985). Periodieke rapportage 64-84 85. The Hague, the Netherlands: Landbouw-Economisch Instituut.

Graham, S. (1983). Results of case-control studies of diet and cancer in Buffalo, New York. Cancer Research 43, 2409-2413.

Graham, S., Dayal, S., Swanson, M., Mittelman, A. \& Valikinson, G. (1978). Diet in the epidemiology of cancer of the colon and rectum. Journal of the National Cancer Institute 61, 709-714.

Graham, S. \& Mettlin, C. (1979). Diet and colon cancer. American Journal of Epidemiology 109, 1-20.

Groenen, P. J. \& Bussink, E. (1988). Alkylating activity in food products - especially sauerkraut and sour fermented dairy products - after incubation with nitrite under quasi gastric conditions. Food and Chemical Toxicology 26, 215-255.

Hill, C. B., Williams, P. H., Carlson, D. G. \& Tookey, H. L. (1987). Variation in glucosinolates in oriental brassica vegetables. Journal of American Society of Horticultural Science 112, 309-313.

Hirayama, T. (1986). Diet and cancer: feasibility and importance of prospective cohort study. In Diet and Human Carcinogenesis. Proceedings of the Second ECP Symposium, Aarhus, Denmark, p. 191 [J. V. Joossens, M. J. Hill and J. Geboers, editors]. Amsterdam: Excerptica Medica.

Jongen, W. M. F. (1988). Co-cultivation of cells as a promising tool in cancer research in vitro. $\mathrm{PhD}$ Dissertation, Agricultural University Wageningen, The Netherlands.

Jongen, W. M. F. (1993). Toxicological methods to study mechanisms of naturally occurring anticarcinogens. In Food and Cancer Prevention: Chemical and Biological Aspects, pp. 383-396 [K. W. Waldron, I. T. Johnson and G. R. Fenwick, editors]. Cambridge: The Royal Society of Chemistry.

Jongen, W. M. F., Alink, G. M., Harmsen, E. G. M. \& Koeman, J. H. (1982). The effect of glutathione conjugation and microsomal oxidation on the mutagenicity of dichloromethane in Salmonella typhimurium. Mutation Research 95, 183-187.

Jongen, W. M. F., Topp, R. J., Tiedink, H. G. M. \& Brink, E. J. (1987). A co-cultivation system as a model for in vitro studies of modulating effects of naturally occurring indoles on genotoxicity of model compounds. Toxicology in vitro $1,105-110$.

Jongen, W. M. F., Topp, R. J., van Bladeren, P. J., Lapré, J., Wienk, K. J. H. \& Leenen, R. (1989). Modulating effects of indoles on benzo(a)pyrene-induced sister chromatid exchanges and the balance between drug-metabolizing enzymes. Toxicology in vitro 3, 207-213.

Loub, W. D., Wattenberg, L. W. \& Davis, D. W. (1975). Aryl hydrocarbon hydroxylase induction by naturally occurring indoles in cruciferous plants. Journal of the National Cancer Institute 54, 985-988. 
McDanell, R., McLean, A. E. M., Hanley, A. B., Heaney, R. K. \& Fenwick, G. R. (1988). Chemical and biological properties of indole glucosinolates (glucobrassicin): A review. Food and Chemical Toxicology 26, 59-70.

McDanell, R., McLean, A. E. M., Hanley, A. B., Heaney, R. K. \& Fenwick, G. R. (1989). The effect of feeding Brassica vegetables and intact glucosinolates on mixed function oxidase activity in livers and intestines of rats. Food and Chemical Toxicology 27, 189-197.

McMillan, M., Spinks, E. A. \& Fenwick, G. R. (1986). Preliminary observations on the effect of dietary Brussels sprouts on thyroid function. Human Toxicology 5, 15-19.

Moldeus, P. (1987). Comparison of model systems for metabolism. In Drug Metabolism: From Molecules to Man, pp. 437-444 [D. Benford, J. W. Bridges and G. G. Gibson, editors]. London: Taylor \& Francis.

National Toxicological Programme (1981). National Toxicological Programme Technical Report on the Carcinogenesis Bioassay of Isoallylthiocyanate. Triangle Park, NC: National Cancer Institute.

Pence, B. C., Buddingh, F. \& Yang, S. P. (1986). Multiple dietary factors in the enhancement of dimethylhydrazine carcinogenesis: main effect of indole-3-carbinol. Journal of the National Cancer Institute 77, 269-276.

Piacek-Llanes, B. G. \& Tannenbaum, S. R. (1982). Formation of an activated N-nitroso compound in nitrite treated fava beans (Vicia faba). Carcinogenesis 3, 1379-1384.

Ponten, J. (1987). Normal versus neoplastic tissue behaviour: what differences are essential? In Concepts and Theories in Carcinogenesis, pp. 3-13 [A. P. Maskens, P. Ebbesen and A. Burny, editors]. Amsterdam: Excerptica Medica.

Slaga, T. J. (1984). Multistage skin carcinogenesis: a useful model for the study of the chemoprevention of cancer. Acta Pharmacologica et Toxicologica 55, Suppl., 107-118.

Slominski, B. A. \& Campbell, L. D. (1987). Gas chromatographic determination of indole glucosinolates a re-examination. Journal of the Science of Food and Agriculture 40, 131-143.

Sparnins, V. I., Venegas, P. L. \& Wattenberg, L. W. (1982). Glutathione-S-transferase activity: enhancement by compounds inhibiting chemical carcinogenesis and by dietary constituents. Journal of the National Cancer Institute 68, 493-495.

Srisangham, C., Salunke, D. K., Reddy, N. R. \& Dull, G. G. (1980). Quality of cabbage. II. Physical, chemical and biochemical modification in processing treatments to improve flavour of blanched cabbage (Brassica oleracea L.). Journal of Food Quality 3, 233-244.

Stoewsand, G. S., Babish, J. B. \& Wimberley, H. C. (1978). Inhibition of hepatic toxicities from polybrominated biphenyls and aflatoxin B1 in rats fed cauliflower. Journal of Environmental Pathology and Toxicology 2, 399-404.

Tiedink, H. G. M., Davies, J. A. R., van Broekhoven, L. W., van der Kamp, H. J. \& Jongen, W. M. F. (1988). Formation of mutagenic $\mathrm{N}$-nitroso compounds in vegetable extracts upon nitrite treatment; a comparison with the glucosinolate content. Food and Chemical Toxicology 26, 947-954.

Tiedink, H. G. M., Davies, J. A. R., Visser, N. A., Jongen, W. M. F. \& van Broekhoven, L. W. (1989). The stability of the nitrosated products of indole, indole-3-acetonitrile, indole-3-carbinol and 4-chloroindole. Food and Chemical Toxicology 27, 723-730.

Tiedink, H. G. M., Hissink, A. M., Lodema, S. M., van Broekhoven, L. W. \& Jongen, W. M. F. (1990). Several known indole compounds are not important precursors of direct mutagenic $N$-nitroso compounds in green cabbage. Mutation Research 232, 199-207.

Tiedink, H. G. M., Malingre, C. E., van Broekhoven, L. W., Jongen, W. M. F., Lewis, J. \& Fenwick, G. R. (1991). The role of glucosinolates in the formation of $\mathrm{N}$-nitroso compounds. Journal of Agricultural and Food Chemistry 39, 922-926.

Topp, R. \& van Bladeren, P. J. (1986). Oxydative biotransformation in primary cultures of chick embryo hepatocytes: induction of cytochrome P-450 and the metabolism of Benzo(a)pyrene. Archives of Toxicology 59, 150-156.

van Bladeren, P. J. (1993). Modulation of biotransformation enzymes by non-nutritive dietary factors. In Food and Cancer Prevention: Chemical and Biological Aspects, pp. 163-175 [K. W. Waldron, I. T. Johnson and G. R. Fenwick, editors]. Cambridge: The Royal Society of Chemistry.

van der Hoeven, J. C. M., Lagerweij, W. J., van Gastel, A., Huitink, J., de Dreu, R. \& van Broekhoven, L. W. (1984). Intercultivar difference with respect to mutagenicity of fava beans (Vicia Faba L.) after incubation with nitrite. Mutation Research 130, 391-394.

van Etten, G. H. (1969). Goitrogens. In Toxic Constituents of Plant Foodstuffs, pp. 103-142 [I. E. Liener, editor]. New York: Academic Press. 
van Etten, G. H. \& Wolff, I. A. (1973). Natural sulphur compounds. In Toxicants Occurring Naturally in Foods, pp. 210-234. Washington, DC: Committee on Food Protection, Food and Nutrition Board and National Research Council, National Academy of Sciences.

Wakabayashi, K., Nagao, M., Ho-Chung, T., Yin, M., Karai, I., Ochiai, M., Tahira, T. \& Sugimura, T. (1984). Appearance of direct-acting mutagenicity of various foodstuffs produced in Japan and South-East Asia on nitrite treatment. Mutation Research 158, 119-124.

Wakabayashi, K., Nagao, M., Ochiai, M., Tahira, T., Yamaizumi, Z. \& Sugimura, T. (1985). A mutagen precursor in Chinese cabbage, indole-3-acetonitrile, which becomes mutagenic on nitrite-treatment. Mutation Research 143, 17-21.

Wakabayashi, K., Nagao, M., Tahira, T., Yamaizumi, Z., Katayama, M., Marumo, S. \& Sugimura, T. (1986). 4-Methoxyindole derivative as nitrosable precursors of mutagens in Chinese cabbage. Mutagenesis 1, 423-426.

Wakabayashi, K., Ochiai, M., Saito, H., Tsuda, M. \& Sugimura, T. (1983). Presence of 1-methyl-1,2,3,4tetrahydro-8-carboline-3-carboxylic acid, a precursor of a mutagenic nitroso compound, in soy sauce. Proceedings of the National Academy of Sciences, USA 80, 2912-2916.

Wattenberg, L. W. (1983). Inhibition of neoplasia by minor dietary constituents. Cancer Research 43, $2449 \mathrm{~s}-2453 \mathrm{~s}$.

Wattenberg, L. W. (1993). Inhibition of carcinogenesis by non-nutrient constituents of the diet. In Food and Cancer Prevention: Chemical and Biological Aspects, pp. 12-24. [K. W. Waldron, I. T. Johnson and G. R. Fenwick, editors]. Cambridge: The Royal Society of Chemistry.

Wattenberg, L. W. \& Loub, W. D. (1978). Inhibition of polycyclic aromatic hydrocarbon-induced neoplasia by naturally occurring indoles. Cancer Research 38, 1410s-1414s.

Wattenberg, L. W., Loub, W. D., Lam, L. K. \& Speir, J. L. (1976). Dietary constituents altering the response to chemical carcinogens. Federation Proceedings 35, 1327-1331.

Wortelboer, H. M., Dekruif, C. A., Vaniersel, A. A. J., Falke, H. E., Noordhoek, J. \& Blaauboer, B. J. (1990). The isoenzyme pattern of cytochrome-P450 in rat hepatocytes in primary culture, comparing different enzyme-activities in microsomal incubations and intact monolayers. Biochemical Pharmacology 40, 2525-2534.

Wright, A. S. (1980). The role of metabolism in chemical mutagenesis and chemical carcinogenesis. Mutation Research 75, 215-223.

Yamaski, H. (1984). Modulation of cell differentiation by tumor promoters. In Mechanisms of Tumor Promotion, vol. 4, pp. 1-43 [T. J. Slaga, editor]. Boca Raton, Florida: CRC Press Inc. 